\title{
Gender Issues in English Language Teaching: Views from Turkey
}

\author{
Eser Ordem - Ömer Gökhan Ulum* \\ Received: October 2, 2019; received in revised form: October 29, 2019; \\ accepted: November 4, 2019
}

\begin{abstract}
:
Introduction: Research into gender diversity and equality of gender in humanities has been mounting since 1960s, when post-modernism and post-structuralism emerged as a reaction to metanarratives of modernization. Methods and approaches in ELT also arose in the same years. However, queer and LGBT identities were intentionally ignored in ELT discipline and departments, although English as a lingua franca was already hailed in the inner circle. This study aimed to unearth the views of young adult learners of English regarding LGBT. Two data collection instruments were administered. A standard scale composed of 21 items that measure homosexuality attitudes was given to the participants $(\mathrm{N}=$ 113). In addition, a semi-structured interview was prepared to elicit the participants' views $(\mathrm{N}=12)$. The results of the study show that most of the participants showed a positive attitude towards LGBT. However, they reported that this topic was never addressed in ELT settings.

Methods: The study was qualitatively designed to elicit the views of young adult learners regarding homosexuality. A standard scale developed by Kite and Deaux (1986) and which was psychometrically sound and reliable to identify the attitudes towards homosexuality and a descriptive phenomenographic research method were used to learn the ideas of the participants. Phenomenographic research method aims to elicit lived experiences of individuals by using experiential description. Although there were 600 young adult learners of English, only 113 of them volunteered to participate in the study. The participants studied English as a foreign language at a public university in Turkey. The average age of the participants was 18. A semi-structured interview was conducted with 12 of the participants.
\end{abstract}

Results: The findings of the study represent that most of the participants ascribed positive attitudes towards homosexuality. Further, a big number of the informants put forward the significance of such concepts as freedom

\footnotetext{
* Eser Ordem, Adana Alparslan Turkes Science and Technology University, Department of Translation and Interpreting, Adana, Turkey; eserordem@gmail.com

Ömer Gökhan Ulum, Mersin University, English Language Teaching Department, Mersin, Turkey; omergokhanulum@gmail.com
} 


\section{Acta Educationis Generalis \\ Volume 10, 2020, Issue 1}

and respect for personal preferences. Besides, an average number of respondents attributed homosexuality as a hormonal disorder encountered in society. The majority of the respondents put an emphasis on the taboo of religion. They revealed that homosexuality is a taboo which is strictly forbidden in Islam and such issues should not be voiced explicitly in our daily life.

Discussion: This study dealt with the issue of LGBT and homosexuality in foreign language settings by taking the views of young adult learners of English into consideration. The results show that homosexuality representation is insufficient in ELT textbooks, curriculum and materials. Although most of the participants showed a positive attitude towards the representation of homosexuality, they noted that LGBT was never addressed in classroom settings. Similarly, Gray (2013) also emphasizes that LGBT identity was not represented in ELT, though considerable progress has been legally made in the UK. Nelson (2002) strongly recommends that queering ESL through discourses may help ESL develop a more diverse attitude towards LGBG identity.

Limitations: This study was limited to only young adult learners in English language teaching. In addition, only two collection data tools, a standard homosexuality scale and a semi-structured interview form, were used. Besides, convenience sampling was used. The sampling was confined to 113 participants for the scale and 12 learners for the semistructured interview form.

Conclusions: The results show that most of the participants have positive attitudes towards acceptance of homosexual identities. Although ELT textbooks and materials tend to discard LGBT identity, teachers and students can queer ELT, EFL and ESL classrooms by using the tenets of progressive education and critical pedagogy. The use of participatory approach can be reinforced and expanded in ELT world encompassing not only inner circle but also outer and expanding circles. Materials, tasks and activities need to be updated in ELT curriculum. The first discussions of equality of gender in post-modernist and post-structuralist theories can be perceptibly seen in ELT by endorsing and developing critical pedagogy.

Key words: gender, identity, homosexuality, queer, LGBT, English language teaching.

\section{Introduction}

Modernity has largely forgotten or tended to ignore gender issues since it has been engaged in developing metanarratives knowingly or unintentionally. However, two world wars that devastated lives of millions of people showed that the tenets and claims of modernity based on reason and logic should be challenged and transformed. Therefore, post-structuralism and post-modernity have developed opposing discourses against modernity by stressing the importance of plurality and multiplicity of knowledge (Best \& Kellner, 1991; 


\section{Acta Educationis Generalis \\ Volume 10, 2020, Issue 1}

Giroux, 1993b). Although post-structuralism and post-modernity are used interchangeably at times, we would rather use post-structuralism since theoretical debates have been more intensively perpetuated around this term. Considering the ideas discussed above, post-structuralism has enabled gender issues to be raised in cultural studies. Therefore, gender has been a discipline of social sciences only in recent decades dating back to 1960s (Butler, 1990; Lewis \& Mills, 2003; Morgan, 2007; Nelson, 1993, 1999; Osad'an, 2012; Osad'an, \& Safir, 2014; Peters, 1996). Gender is an umbrella term that includes queer theory and LGBT issues as well. Although some researchers have conceptualized gender within binary logic and essentialism, Butler (1990) has placed gender on a large spectrum by emphasizing that gender is an act that we do each day through language because without discourses and expressions, gender per se does not exist. Therefore, gender is socially and historically constructed, which makes it fictitious. Thus, subjects do not perform gender acts consciously because discourses precede and mold gender. In line with this idea, heteronormativity is created by social dialogue as if it contains essentialist nature. However, when homosexuality is performed in society, they are controlled, otherized and even punished. This radical distinction between heterosexuality and homosexuality is produced under the effect of discourses that have been historically, politically and socially constructed and reinforced. Since this binary logic has been dominant in discussions of gender, queer theory has striven to bring a different perspective to gender by including the idea of multiplicity and plurality within the framework of humanistic psychology (Gáborová, 2011) and post-structuralism (Peters, 1996).

\section{Theoretical background}

Although some disciplines in humanities expand and develop the horizon of gender issues, the discipline of English language teaching has been delayed to include gender issues and diversity into teaching per se, even if this discipline has produced almost 30 methods to teach English since 1960s (Thornbury, 2017). It is a very clear fact that gender issues have been often ignored in these methods because presence of critical pedagogy has been rarely hailed in English language teaching (therefore ELT). Although Gray (2013) partially supports the idea that capitalism has supported gender diversity, this study rejects this idea because capitalism uses all agents and genders in societies to use and to be used. Thus, gender diversity becomes victims of capitalism. Legal acceptance of nonbinary gender in certain countries is not equal to acceptance of the whole society. Capitalism ignores gender equality in ELT market because textbooks, curriculum, syllabi and tasks which include issues regarding equality of gender in countries incorporating outer and expanding circles may not work for the interests of capitalism (Gray, 2013; Thornbury, 2017). Capitalism, in this sense, victimizes LGBT individuals to gain more profits in these outer and expanding circles. Gray (2013) notes the fact that ELT has been the victim of 


\section{Acta Educationis Generalis \\ Volume 10, 2020, Issue 1}

commercialism. Denial and deliberate rejection of recognizing LGBT identity is based on normalizing heteronormativitiy in ELT (Barozzi \& Ojeda, 2010; Nelson, 1999).

In criticisms of post-colonial ideologies and analysis of social constructionist theory, it can be said that gender is socially and culturally constructed (Lewis \& Mills, 2003; Walters, 2005). However, cultural politics criticizes practices, particularly educational ones, in certain cultures (Giroux, 1988, 1993a). Thus, ELT programs intentionally have been marginalizing and otherizing LGBT identities (Gray, 2013; Nelson, 1999). They are treated as if they have been excluded from the society. The emergence of post-modernism and poststructuralism has produced fruitful analyses regarding gender diversity from women, feminism to queer bodies and identities (Best \& Kellner, 1991; Morgan, 2007; Namaste, 1994; Peters, 1996; Renn, 2010).

In accordance with post-modernist and post-structuralist theories, methods of post-method era in ELT have not been represented in textbooks, curricula and teacher talks (Nelson, 1993, 1999). One of the prominent methods of postmethod era is participatory approach that deals with ideology and power relations in ELT (Tollefson, 2007). However, widespread use of this approach has not been seen in ELT discipline. Therefore, gender issues have been deliberately framed and discarded by global textbooks. Genders issues incorporate feminism, LGBT, queer theory and alternative sexes (Gray, 2013). Lack of discussions regarding gender issues in ELT is a manifestation of western hypocrisy in the world arena.

Barış and Esra (2014) report the fact that in the context of Turkey, these issues might be riskier for global market. LGBT in Turkey was able to hold their first pride parade along with almost 30 people only in İstanbul in 2003 (Y1lmaz \& Göçmen, 2015). The first pride parade in the capital city of Turkey was held in 2006. However, the first official pride parade was organized in Bursa, the fourth biggest city in Turkey where LGBT individuals were attacked on. In 2011, one of the biggest pride parades was held with the support of two leftist political parties in Turkey. However, it is assumed that the most immense pride parade was arranged in 2013. However, since 2015, LGBT parade has been banned by the government on the pretext that this parade could lead to some negative incidents, although almost 13 parades were successfully and uneventfully organized previously. Legally same-sex marriage is not allowed in Turkey. However, an individual can choose to be LGBT individual (Orta \& Camgöz, 2018).

This study aims to unravel the views of young adult learners of English about homosexuality in ELT in Turkey. It is important to develop discursive practices in ELT situated in expanding circle. Although the countries in the inner circle tend to avoid this issue owing to commercial anxiety, the countries in outer and expanding circles experience social, cultural and political problems while 


\section{Acta Educationis Generalis \\ Volume 10, 2020, Issue 1}

endeavoring to represent homosexual identity in ELT disciplines largely shaped by inner circle' global market and commercial aims.

\section{Methodology}

The study was qualitatively designed to elicit the views of young adult learners regarding homosexuality. A standard scale developed by Kite and Deaux (1986) and which was psychometrically sound and reliable to identify the attitudes towards homosexuality and a descriptive phenomenographic research method were used to learn the ideas of the participants. Phenomenographic research method aims to elicit lived experiences of individuals by using experiential description. This research method stresses the importance of subjectivity and the search for meaning of certain experiences and topics (Feldon \& Tofel-Grehl, 2018; Marton, 1981, 1988; Willis, 2018).

\subsection{Participants}

Although there were 600 young adult learners of English, only 113 of them volunteered to participate in the study. The participants studied English as a foreign language at a public university in Turkey. The average age of the participants was 18 . Gender and names were kept confidential because of the nature of the topic investigated. All of the participants described themselves as Muslims. Their mother tongue was only Turkish. The participants had English only at A1.1 level before entering the university because a placement test was conducted before they were placed into classrooms at different levels. Four basic skills composed of reading, writing, listening and speaking were taught in accordance with the curriculum. The participants learned English from global textbooks, MacMillan, Pearson and Their level ranged between A2 and B2. The participants had English teachers from both national and international backgrounds. A semi-structured interview was conducted with 12 of the participants.

\subsection{Procedure}

The participants were informed about the content of the study. Before conducting the study, brief information regarding LGBT was presented. Later, they were given the questionnaire in one session in 5 different classes. In addition, the participants $(\mathrm{N}=12)$ were interviewed and the study was centered on certain themes. Lastly, the consent form was signed by the participants.

\subsection{Data collection}

The homosexuality scale developed by Kite and Deaux (1986) was used. In addition, the participants were given some interview questions about their attitudes towards and views regarding homosexuality. The interview questions were prepared by adapting the interview questions prepared by Gray (2013). The researchers also formed additional five interview questions by taking the 


\section{Acta Educationis Generalis \\ Volume 10, 2020, Issue 1}

classification by Gray into consideration by taking two psychologists and experts' opinions specializing in studies on homosexuality and LGBT.

\subsection{Data analysis}

The data collected from the scale was analyzed through SPSS. The mean value of each item was presented. If the score obtained from the scale is closer to 5, it means that the participants have a more positive attitude towards acceptance of homosexual identity. If the score obtained from the scale is less than 2.40, it means that they have a negative attitude towards acceptance of homosexual identity. In addition to the scale, the views of 12 participants were examined through inductive content analysis.

\section{Results}

In this section, the results of the study and the findings are described based on the data obtained from the participants by means of the instruments. They are grouped under the titles of the categories from the questionnaire (Table 1).

\section{Table 1}

\section{Scale results of EFL students' homosexuality attitudes}

\begin{tabular}{|c|c|c|}
\hline \multicolumn{2}{|c|}{ Item } & Mean \\
\hline 1 & $\begin{array}{l}\text { Finding out that an artist was gay would have no effect on my } \\
\text { appreciation of his/her work. }\end{array}$ & 3.92 \\
\hline 2 & $\begin{array}{l}\text { I would look for a new place to live if I found out my roommate } \\
\text { was gay. }\end{array}$ & 3.25 \\
\hline 3 & I would not mind being employed by a homosexual. & 3.22 \\
\hline 4 & I won't associate with known homosexuals if I can help it. & 3.21 \\
\hline 5 & $\mathrm{~d}$ having a homosexual friend. & 3.17 \\
\hline 6 & $\begin{array}{l}\text { sex holding hands or displaying } \\
\text { ing. }\end{array}$ & 3.06 \\
\hline 7 & exual in an election for public office. & 3.02 \\
\hline 8 & ership in an organization just because it & 2.98 \\
\hline 9 & $\begin{array}{l}\text { en two males or two females is quite different from } \\
\text { en two persons of the opposite sex. }\end{array}$ & 2.96 \\
\hline 10 & $\begin{array}{l}\text { eptance of homosexuality in our society is aiding } \\
\text { of morals. }\end{array}$ & 2.93 \\
\hline 11 & $\begin{array}{l}\text { If I knew someone were gay, I would still go ahead and form a } \\
\text { friendship with that individual. }\end{array}$ & 2.84 \\
\hline 12 & $\begin{array}{l}\text { Homosexuals are more likely to commit deviant sexual acts, such } \\
\text { as child molestation, rape, and voyeurism (Peeping Toms), than are } \\
\text { heterosexuals. }\end{array}$ & 2. \\
\hline 13 & I do not really find the thought of homosexual acts disgusting. & 72 \\
\hline
\end{tabular}


14 Homosexuals should be forced to have psychological treatment. 2.68

15 I would not be afraid for my child to have a homosexual teacher. $\quad 2.56$

16 Homosexuality, as far as I'm concerned, is not sinful. 2.54

17 Homosexuals should be kept separate from the rest of society (i.e. $\quad 2.52$ separate housing, restricted employment).

18 Homosexuality is a mental illness.

19 Gays dislike members of the opposite sex.

20 I see the gay movement as a positive thing. 2.38

21 If I were a parent, I could accept my son or daughter being gay. $\quad 2.38$

By looking at the mean $(\overline{\mathrm{x}})$ score 3.92 , one can clearly understand that the only item that is agreed by the respondents is the 1st item finding out that an artist was gay would have no effect on my appreciation of his/her work. Besides, it is easily observed from the counted mean scores that the respondents were neutral about the following items: the 2 nd item I would look for a new place to live if I found out my roommate was gay $(\overline{\mathrm{x}}=3.25)$; the 3 rd item I would not mind being employed by a homosexual ( $\bar{x}=3.22)$; the 4 th item I won't associate with known homosexuals if I can help it $(\bar{x}=3.21)$; the 5 th item I would not mind having a homosexual friend $(\bar{x}=3.17)$; the 6th item Two individual of the same sex holding hands or displaying affection in public is revolting $(\bar{x}=3.06)$; the 7 th item I would vote for a homosexual in an election for public office $(\bar{x}=3.02)$; the 8th item I would not decline membership in an organization just because it had homosexual members $(\vec{x}=2.98)$; the 9th item The love between two males or two females is quite different from the love between two persons of the opposite sex $(\bar{x}=2.96)$; the 10th item The increasing acceptance of homosexuality in our society is aiding in the deterioration of morals $(\bar{x}=2.93)$; the 11th item If I knew someone were gay, I would still go ahead and form a friendship with that individual $(\bar{x}=2.84)$; the 12 th item Homosexuals are more likely to commit deviant sexual acts, such as child molestation, rape, and voyeurism (Peeping Toms), than are heterosexuals $(\bar{x}=2.74)$; the 13th item I do not really find the thought of homosexual acts disgusting $(\bar{x}=2.72)$; the 14th item Homosexuals should be forced to have psychological treatment $(\bar{x}=2.68)$; the 15th item I would not be afraid for my child to have a homosexual teacher $(\bar{x}=2.56)$; the 16th item Homosexuality, as far as I'm concerned, is not sinful ( $\bar{x}=2.54)$; and the 17th item Homosexuals should be kept separate from the rest of society (i.e., separate housing, restricted employment $)(\overline{\mathrm{x}}=2.52)$. On the other hand, there are some items on which the respondents disagree. In the same vein, the mean $(\overline{\mathrm{x}})$ scores of these items represent that the 18th item Homosexuality is a mental illness $(\bar{x}=2.49)$; the 19 th item Gays dislike members of the opposite sex $(\overline{\mathrm{x}}=2.48)$; the 20th item I see the gay movement as a positive thing $(\overline{\mathrm{x}}=2.38)$; and the 21 st item If I were a parent, I could accept my son or daughter being gay $(\overline{\mathrm{x}}=2.38)$ are disagreed by the respondents. 


\section{Acta Educationis Generalis \\ Volume 10, 2020, Issue 1}

\subsection{Findings related to representation of $L G B T$ in immediate social environment}

The findings of the study represent that most of the participants ascribed positive attitudes towards homosexuality. Further, a big number of the informants put forward the significance of such concepts as freedom and respect for personal preferences. Besides, an average number of respondents attributed homosexuality as a hormonal disorder encountered in society. Excerpts from the informants' views are as follows:

- The preferences of people are none of my business. People can do whatever they want. With a little bit more respect, we could have had a better life. Nobody should interrupt others' life. Nobody knows about what, where, and how people lived before. If people had cared their own business, corrected their mistakes, and been more tolerant, everything would be better. In brief, let's not direct people (P1).

- Having LGBT around would not disturb me. Everyone is free in their preferences. Those who have no respect for LGBT actually disturb me. LGBT people are also humans and they have a place in society. They sometimes protest as they are humiliated and abused by other people. They should not cross the borders of protest, though (P3).

- LGBT people are individuals of the community and they may be different from us. I can show them respect if they do not cross my border. I am not strict about this issue as I suppose, it is a hormonal disorder. They do not disturb me, if they are well behaved (P5).

The participants reported that they had a positive understanding of LGBT people around them. Respect and diversity were emphasized in their remarks. In addition, the participants were aware of the negative attitudes of the larger society in Turkey. Therefore, it can be said that the learners developed a positive attitude towards LGBT individuals.

\subsection{Findings related to representation of $L G B T$ in daily life}

The majority of the respondents put an emphasis on the taboo of religion. They revealed that homosexuality is a taboo which is strictly forbidden in Islam and such issues should not be voiced explicitly in our daily life. However, such aspects as homosexuality as a social reality of everyday life, tolerance and intolerance towards encountering homosexuality in our daily life were uttered by the informants. The related excerpts are as follows:

- I do not appreciate LGBT formation, but their existence around does not irritate me much. It is ok if they are not close to me or my family. I think this is an illness and it should be cured. I do not say they should be exempted from society, but this is a Muslim country and this formation is against our societal norms. LGBT people should be regained and integrated in the society after the required treatments (P7). 


\section{Acta Educationis Generalis \\ Volume 10, 2020, Issue 1}

- I think it is a psychological disorder to be a member of LGBT. The next phase of LGBT formation means terror and it will be too harmful for the society. They have no aim apart from destroying Islam. Such formations as LGBT and their activities must be stopped and LGBT people should be exposed to psychological treatment (P8).

- It does not disturb me in daily life. If they do not disturb me, I have respect for them. Besides, I believe they should be tolerated since, as far as I know, it is a hormonal disorder (P9).

Although some participants said that they respect LGBT individuals, they regard LGBT individuals as hormonal disorders that need to be treated. In addition, views in Islam affected their approach towards LGBT individuals.

\subsection{Findings related to representation of LGBT in classroom settings}

Capturing attitudes based on informants' responses, it was detected that homosexuality or such affaire should be integrated into classroom settings as long as not diverging from the lane of science. However, a number of informants also uttered the harmful effects of mentioning such issues in the classroom setting unlike those hinting on the worthiness of equality in educational settings. Excerpts from the informants' views are as follows:

- I look at the issue of LGBT in a scientific way which is very different from others' point of view. God created every male with $2 \%$ female hormone inside, while s/he created every female with $2 \%$ male hormone in the body. Sometimes, the percentage of this hormone may be more than $2 \%$, which is an illness that should be tolerated. So, such issues may be integrated into classroom settings (P4).

- In our current era, it is very dangerous to restrict human rights. We are born as free and we live freely. So, those who are against LGBT should be educated, in my point of view. The question is not LGBT, but equality. There should be equality among all people. No one can hinder each other. So, there is no harm in mentioning such issues in educational settings, as long as not exaggerated (P5).

The participants' views regarding LGBT issue in classroom settings are that tolerance can be developed and that equality is the main issue while approaching LGBT individuals. They also emphasize that a scientific approach should be adopted. However, the problem in their views is that LGBT issue is still regarded as a disorder by using pseudo-scientific data. Therefore, a critical approach needs to be developed by enabling them to negotiate this issue and by inviting LGBT individuals into classroom settings or using different tasks such as showing documentary films or critical reading passages. 


\section{Acta Educationis Generalis \\ Volume 10, 2020, Issue 1}

\section{Discussion}

This study dealt with the issue of LGBT and homosexuality in foreign language settings by taking the views of young adult learners of English into consideration. The results show that homosexuality representation is insufficient in ELT textbooks, curriculum and materials. Although most of the participants showed a positive attitude towards the representation of homosexuality, they noted that LGBT was never addressed in classroom settings. Similarly, Gray (2013) also emphasizes that LGBT identity was not represented in ELT, though considerable progress has been legally made in the UK. Nelson (2002) strongly recommends that queering ESL through discourses may help ESL develop a more diverse attitude towards LGBG identity. The first remarks regarding queer and LBT identity in ELT started in different contexts around 1990s. Nelson (2008) reports that recognition of LGBT identity is only nascent in ELT that should get rid of heteronormative education. The positive attitudes of females towards homosexuality may have resulted from the fact that females also consider themselves at a disadvantage in the society. Thus, they may have developed the feeling empathy towards homosexual and LGBT groups (Huić, Jelić, \& Kamenov, 2016). Nelson (2010) also reports a study on a gay immigrant student in a foreign language class in the USA who could not express himself freely and avoided mentioning issues about gender diversity. Therefore, she suggests that limitations on gay topics need to be addressed in ESL classrooms. Teachers ought to take risks by providing topics that include gender diversity and sexual identities. By expanding on this topic, Paiz (2018) recommends that ESL teachers need to receive queer training to raise awareness of diverse identities and prepare curriculum, syllabus and tasks in accordance with queer topics.

When considering the emerging literature, one can be misled to think that queer and LBGT identity are widespread in ELT (Barozzi \& Ojeda, 2010; Nelson, 2002; Tollefson, 2007). However, this literature applies to mostly inner circle countries. In Turkey, this issue is among the taboo topics that may disturb some learners situated in relatively conservative culture (Barış \& Esra, 2014). Considering the tenets of critical pedagogy, it can be said that in the context of Turkey, heterosexuality is performatively and socially constructed in ELT departments and classrooms (Barış \& Esra, 2014; Sarıçoban \& Kazazoğlu, 2012; Tekin, 2011a). Tekin (2011b) conducted a study with Turkish EFL students and concluded that $40 \%$ of EFL learners had a positive attitude towards negotiation of homosexuality. Güney (2018) carried out a study with the undergraduates majoring in ELT department and showed that the participants were mentally ready to negotiate queer issues. However, the participants reported that they could avoid discussing queer issues in their future classroom settings with young learners since the cultural setting might not be appropriate because the ministry of Turkish National Education may not allow them to discuss these issues. Indeed, this perspective might prove to be accurate because 


\section{Acta Educationis Generalis \\ Volume 10, 2020, Issue 1}

Council of Higher Education (CHE) in Turkey banned discussing gender diversity at universities in 2019 by stating that negotiating gender diversity might be a threat to Turkish culture and family culture because those in power in Turkey tend to define almost $95 \%$ of Turkish people as Muslims. Therefore, Islamic values are often reinforced in education system of Turkey. However, education encompassing homosexuality is ignored. Halstead \& Lewicka (1998) note that Islam is already familiar with topics regarding homosexuality which needs to be included into education system of Muslim countries from the age of 8 on to address minority communities. However, neither national nor international textbooks tend to mention topics of homosexuality because of commercial, social and cultural concerns. Therefore, Halstead \& Lewicka (1998) bring a cultural and political criticism towards this understanding. Negotiating identities and gender equality can contribute to emergence and acceptance of these identities in ELT.

Although language is seen as one of the most effective tools in transforming society in ELT where English as a lingua franca should be emancipatory, the potent effect of English is not used in ELT settings. Thus, English as a lingua franca is rendered weak, feeble, pale and an orphan because it cannot use its energia in Aristotelian sense. English as a lingua franca arising from inner circle remains handicapped and experiences solitary confinement by itself with little or no effect on society. Therefore, it is true that Philipson (2017) evaluates the current situation of English as mythologized Lingua franca. Gray (2013) insistently stresses the importance of use of LGBT materials and textbooks in ELT departments because theoretical negotiations and legal acceptance of LGBT in certain countries do not suffice to endorse LGBT identities. Commercialism should not be the only motive to publish ELT textbooks because these textbooks guide minds of participants (teachers, learners, administrators) in a heteronormative way that should be challenged. Ilyas (2017) also mentions the absence of inclusion of homosexuality in ELT textbooks in Indonesia withing the framework of critical thinking paradigm by showing that a Muslim writer in Canada was attacked since homosexuality was addressed and that socio-political context in Indonesia had religious intolerance, which also hindered inclusion of topics of homosexuality in ELT. Mambu (2016) from Java, Indonesia shows that teachers should enable EFL learners from different religious backgrounds to discuss unfavorable issues considering the perspectives of critical interfaith in classroom settings so that their negotiations can produce fruitful discourses. Thus, Mambu's study can be a good model for EFL learners to discuss issues of homosexuality because critical interfaith dialogues are encouraged. In line with these ideas and discussions, Gray (2013) also insistently prioritizes the widespread use of LGBT materials in ELT settings. This study showed that the majority of the participants feel prepared to encounter LGBT individuals at cognitive level. However, it still 


\section{Acta Educationis Generalis \\ Volume 10, 2020, Issue 1}

remains unclear whether they are ready to experience shared lives in the same environment.

\section{Conclusions}

This study intended to elicit the views of young adult learners of English regarding homosexuality. The results show that most of the participants have positive attitudes towards acceptance of homosexual identities. Although ELT textbooks and materials tend to discard LGBT identity, teachers and students can queer ELT, EFL and ESL classrooms by using the tenets of progressive education and critical pedagogy. The use of participatory approach can be reinforced and expanded in ELT world encompassing not only inner circle but also outer and expanding circles. Materials, tasks and activities need to be updated in ELT curriculum. The first discussions of equality of gender in postmodernist and post-structuralist theories can be perceptibly seen in ELT by endorsing and developing critical pedagogy. Otherwise, the gap between theory and practice in ELT may be hard to be bridged. What is more, ELT can be the pioneer to guide societies into a more emancipatory and transformative form. In future studies, ELT should revise and transform its own curricula, textbooks, syllabi and materials in the changing world. Changes in ELT might be commenced through teacher talk, that is, discursive practices that may contribute to the performativity of gender.

\section{References}

Barış, E., \& Esra, K. (2014). Yeni toplumsal hareketlerin sınıf dinamiği: Türkiye LGBT Hareketi. Marmara University Journal of Political Sciences, 2(1), 93-113.

Barozzi, S., \& Ojeda, J. R. G. (2016). Sexual identities in EFL at primary school level: A pre-service teachers' perspective from Spain. Porta Linguarum: Revista Internacional de Didáctica de Las Lenguas Extranjeras, 25, 9-20.

Best, S., \& Kellner, D. (1991). The postmodern theory: Critical interrogations. London: McMillan Educational Ltd.

Butler, J. (1990). Gender trouble. Feminism and the subversion of identity. New York: Routledge.

Feldon, D. F., \& Tofel-Grehl, C. (2018). Phenomenography as a Foundation for Mixed Models Research. American Behavioral Scientist, 62(7), 887-899.

Gáborová, L. (2011). Humanistic psychology in the university preparation of future teachers. Acta Technologica Dubnicae, 1(2), 1-15. https://doi.org/ 10.1515/atd-2015-0041

Giroux, H. (1988). Teacher education as cultural politics. In H. Giroux, Schooling and the struggle for public life (pp. 188-202). Minneapolis: University of Minnesota Press. 


\section{Acta Educationis Generalis \\ Volume 10, 2020, Issue 1}

Giroux, H. (1993a). Living dangerously: Multiculturalism and the politics of difference. New York: Peter Lang.

Giroux, H. (1993b). Border crossing: Cultural workers and the politics of education. New York: Routledge.

Gray, J. (2013). LGBT Visibility and Heteronormativity in ELT Materials. In J. Gray (Ed.), Critical Perspectives of Language Teaching Materials (pp.4063). Basingstoke: Palgrave Macmillan.

Güney, Ö. (2018). Queering teacher education programs: perceptions of preservice EFL teachers towards queer issues (Doctoral dissertation). Ankara: Bilkent University.

Halstead, J. M., \& Lewicka, K. (1998). Should homosexuality be taught as an acceptable alternative lifestyle? A Muslim perspective. Cambridge Journal of Education, 28(1), 49-64.

Huić, A., Jelić, M., \& Kamenov, Ž. (2016). What predicts the willingness of heterosexual persons to behave in a positive or negative manner towards homosexual persons? Kriminologija \& socijalna integracija: časopis za kriminologiju, penologiju i poremećaje u ponašanju, 23(2), 110-141.

Ilyas, H. P. (2017). Historical Perspective: The Development of Critical Thinking in Indonesian ELT. Journal of ELT Research, 2(2), 89-102.

Kite, M. E., \& Deaux, K. (1986). Attitudes toward homosexuality: Assessment and behavioral consequences. Basic and Applied Social Psychology, 7, 137162 .

Lewis, R., \& Mills, S. (Eds.). (2003). Feminist postcolonial theories: A reader. New York: Routledge.

Mambu, J. E. (2016). Investigating students' negotiation of religious faiths in ELT contexts: A critical spiritual pedagogy perspective. Critical Inquiry in Language Studies, 13(3), 157-182.

Marton, F. (1981). Phenomenography: Describing conceptions of the world around us. Instructional Science, 10, 177-200.

Marton, F. (1988). Phenomenography: Exploring different conceptions of reality. In D. M. Fetterman (Ed.), Qualitative approaches to evaluation in education: The silent scientific revolution (pp. 176-205). New York: Praeger.

Morgan, B. (2007). Poststructuralism and applied linguistics: Complementary approaches to identity and culture in ELT. In J. Cummins, \& C. Davison (Eds.), International handbook of English language teaching (Vol. 2) (pp. 949-968). Norwell, MA: Springer Publishers.

Namaste, K. (1994). The politics of inside/out: Queer theory, poststructuralism, and a sociological approach to sexuality. Sociological Theory, 12, 220-231.

Nelson, C. (1993). Heterosexism in ESL: Examining our attitudes. TESOL Quarterly, 27(1), 143-150. 


\section{Acta Educationis Generalis \\ Volume 10, 2020, Issue 1}

Nelson, C. (1999). Sexual identities in ESL: Queer theory and classroom inquiry. TESOL Quarterly, 33(3), 371-391.

Nelson, C. (2002). Why Queer Theory is useful in teaching: A perspective from English as a second language teaching. Journal of Gay \& Lesbian Social Services, 14( 2), 43-53.

Nelson, C. D. (2008). Sexual identities in English language education: Classroom conversations. New York and London: Routledge.

Nelson, C. D. (2010). A gay immigrant student's perspective: Unspeakable acts in the language class. Tesol Quarterly, 44(3), 441-464.

Orta, İ. M., \& Camgöz, S. M. (2018). Türkiye'de Yapılan Homofobi Çalışmalarına Genel Bir Bakış. (A general perspective towards homophobic studies in Turkey.). DTCF Journal, 58(1), 409-439.

Osad'an, R. (2012). Gender Stereotypes and Elementary School Teachers. Acta Technologica Dubnicae, 2(2), 25-29. https://doi.org/10.1515/atd-2015-0057

Osad'an, R., \& Safir, Y. (2014). A Cross-Cultural Examination of Curriculum and Sexuality Outcomes in Primary School. Acta Technologica Dubnicae, 4(2), 67-72. https://doi.org/10.1515/atd-2015-0007

Paiz, J. M. (2018). Queering ESL teaching: Pedagogical and materials creation issues. TESOL Journal, 9(2), 348-367.

Peters, M. (1996). Poststructuralism, Politics, and Education. Critical Studies in Education and Culture. Bergin and Garvey: Westport.

Phillipson, R. (2017). Myths and realities of 'global' English. Language Policy, 16(3), 313-331. https://doi.org/10.1007/s10993-016-9409

Renn, K. A. (2010). LGBT and queer research in higher education: The state and status of the field. Educational Researcher, 39(2), 132-141.

Sarıçoban, A., \& Kazazoğlu, S. (2012). Topic preferences of Turkish ELT students and teachers in text books. Sino-US English Teaching, 9(2), 887892.

Tekin, M. (2011a). Discussing the unspeakable: A study on the use of taboo topics in EFL speaking classes. Journal of Theory and Practice in Education, 7(1), 79-110.

Tekin, M. (2011b). Breaking the shell: A study on Turkish students' reactions towards sexual identity issues in the language classroom. Gay and Lesbian Issues and Psychology Review, 7(3), 216-231.

Thornbury, S. (2017). Scott Thornbury's 30 language teaching methods Google EBook: Cambridge handbooks for language teachers. Cambridge University Press.

Tollefson, J. W. (2007). Ideology, language varieties, and ELT. In J. Cummins, \& C. Davison (Eds.), International handbook of English language teaching (pp. 25-36). New York: Springer. 


\section{Acta Educationis Generalis \\ Volume 10, 2020, Issue 1}

Walters, M. (2005). Feminism: a very short introduction. Oxford: Oxford University Press.

Yılmaz, V., \& Göçmen, I. (2015). Summary results of the social and economic problems of lesbian, gay, bisexual and transsexual (LGBT) individuals in Turkey research. Center for Policy and Research on Turkey, 4, 97-105.

Willis, A. S. (2018). The efficacy of phenomenography as a cross-cultural methodology for educational research. International Journal of Research \& Method in Education, 41(5), 483-499. 